\title{
Selective Appraisal of the Liability of Financial Institutions with Use of E - Banking and Payment Systems
}

\author{
Dr. Charles Ezeagba Emenike
}

Accountancy Department, Nnamdi Azikiwe University, Awka

\section{Doi:10.5901/mjss.2015.v6n3p515}

\section{Abstract}

This paper seeks to examine the impact of Information and Communication Technology (ICT) on the provision of financial payment services in Nigeria. We have carried out a selective appraisal of the liability of financial institutions as well as payment system providers that have deployed ICT tools in the delivery of their services in relation to cases of forgery, fraud, mistake and system failure; while assuming at all times that the customer or client is faultless, The paper examines the selected issues within the precincts of the extant legal regime in Nigeria with a view to ascertaining if they suffice for the regulation of the relationship between customers and financial institution.

\section{Introduction}

Information and Communication Technology (ICT) and its tools have had an unprecedented impact on financial Institutions and payment systems in Nigeria in the past decade. For example, the issuance of debit cards by financial institutions and card payment schemes like phone cards provide a good source of liquidity, income and loan for the issuer. This is because, upon receipt of payment for the electronic value that is issued, there is a time lag before the value purchased and issued is redeemed and spent, thus, creating a float which the issuer can make use of, interest free. (Aniyic, 2004) More obvious, is the fact that the incorporation of ICT tools into the mechanics of the Nigerian banking and payment system services poses challenges to the Nigerian legal jurisprudence as a result of the fact that it has raised legal issues some of which our existing legal framework seems illequipped to deal with. For example, while the advancements and innovations in ICT are progressing at a geometric rate, the necessary regulatory framework is progressing at an arithmetic rate. Also, electronic products such as the Automated Teller Machine (ATM), which was invented to ease the problem of cash withdrawal is now fast becoming a nemesis for the users as complaints trail its use. This development has given birth to more than was bargained for by all parties to the relationship in terms of liability which usually is apportioned on the basis of fault.

\section{Forgery}

The possibility of forgery of ICT -tools utilised by financial institutions is a reality. Most electronic products deployed by financial institutions in Nigeria are based on the smart card technology and they have fallen prey to forgers as the technology for this exists and is within the reach of all who can pay for same.

Smart cards like ATM, Debit and Credit cards have fallen prey to forgers; the technology for this exists and is within the reach of all who can pay for same. Our focus is the determination of the liability of financial institutions whose e-tools have been fraudulently copied and as a result of which a client suffers is a determination of the legal status of a smart card and the accompanying PIN: combined are they analogous to a signed cheque? It is submitted that combined, a smart card and PIN are analogous to a signed cheque. This submission is premised on the knowledge of what the signed cheque and the smart card combined with the PIN are used to accomplish.

A signed cheque is used to convey mandate to the financial institution. This is the use to which a smart card and PIN is put. To make possible their use, the signature and the PIN are a shared secret: the financial institution usually has in its database; a sample of the customer's signature and in the case of smart cards, the financial institution also has in its database the PIN of its customer with which it compares and confirms the identity and mandate of the customer. It is this mandate that nowadays, is being forged. Thus, where a card which was fraudulently copied or stolen and the fraudulently acquired PIN is used to interact with a financial institution with the aim of making a withdrawal, it is submitted that the mandate which is consequently conveyed when the duplicate card and the fraudulently acquired PIN is used, amounts to 
a forged mandate and is tantamount to a no mandate from the customer/ client and the financial institution cannot premise its debiting the latter's account on this. And in a situation where there is no mandate preceding the debiting of a client/ customer's account, it is submitted that a financial institution who has debited a client' account is liable to make a refund of the amount debited without mandate to the affected client/ customer. This is because it is trite that a financial institution is only entitled to pay in accordance with a valid mandate from its customer; that a forged mandate is not a valid mandate.

Furthermore, certain concepts contained in the Bills of Exchange Act which does not relate to negotiability are adaptable to e-banking and payment systems services and are thus, capable of making the financial institution's liability for the forgery as espoused above. The Act provides that where a signature is forged, the forged signature is wholly inoperative and no right to enforce payment thereof against any party thereto can be acquired through or under that signature. (See section 24, Bills of Exchange Act, Cap. B8 Laws of the Federation of Nigeria, 2004; Latunji v. Cooperative Bank of Western Nigeria Ltd.(1979); Nig. Advertising Service Ltd. v. UBA Ltd. (1965).

Thus, it is submitted that in relation to an e-service or product provided by a financial institution of which there has been a forgery which was not due to the customer's fault or negligence, the liability accruing there from, is that of the financial institution. (Nig. Advertising Service Ltd. v. UBA Ltd., supra)

\section{Fraud}

Statistics show that financial losses due to bank fraud in Nigeria increased from N105 million in 1989 to N6,367 million in 1999. This shows approximately $98 \%$ increase in loss due to bank fraud within a ten - year period (Igbinovia, 2003). Fraud in financial institutions which have deployed ICT - tools manifests in various forms and could be perpetuated by either staffs of the financial institutions, customers, or third parties. The situation is alarming and has given birth to a myriad of reactions. The Central Bank of Nigeria (CBN) recognising the pervasiveness of e-banking and payment systems in Nigeria and the propensity of them being used to perpetuate fraud, formulated the Central Bank of Nigeria Guidelines on Electronic Banking in Nigeria of August, 2003 (hereafter referred to as the 'Guidelines'). These Guidelines are to regulate the use of e-tools as well as provision of e-serb by financial institutions in Nigeria.

The Guidelines are an attempt at checkmating fraud perpetuated by bank staff and criminal third parties. Amongst other things, they stipulate that banks providing internet banking services should put in place procedures for the maintenance of the bank's website, ensure that only authorised staff are allowed to update or change information on the website and ensure that the Internet Service Provider (ISP) has incorporated a firewall to protect the bank's website where it is out - sourced. Thus, where the bank, due to its negligence and/or professional laxity, fails to comply with the directives of the $\mathrm{CBN}$, it is submitted that the delinquent bank is liable to the customer who is defrauded subsequent to an unauthorised access of his/her records or information with the bank.

The foregoing submission is premised on the fact that a bank is under a duty to exercise reasonable care and skill with regards to the customer's affair (Benson v. Otubor (1975); Agbanelo v. UBN [2007]) and that the Guidelines are a re - statement of that duty. In Agbanelo v. UBN Ltd. (supra), the Supreme Court held per Ayoola, JSC that:

A bank has a duty under its contract with its customer to exercise reasonable care and skill in carrying out its part with regard to operations within its contracts with its customers. The duty to exercise reasonable care and skill extends over the whole range of banking business within the contract with the customer.

Thus, when a bank fails to exercise reasonable care and skill with regards to its customers' affairs, it is submitted that the bank is negligent and has failed to observe the standard expected of a reasonable banker. The foregoing is applicable, mutatis mutandi to other non-banking financial institutions and payment systems providers. Furthermore, the Guidelines state that bank will be considered liable for fraud arising from card skimming and counterfeiting in relation to ATM cards.

\section{Mistake}

The mistakes that could probably occur in relation to transactions involving financial institutions providing services along the line of e-banking and payment systems and their customers are numerous. For example, in relation to electronic credit or funds transfer, where a paying institution due to an administrative or clerical mistake and under a mandate given by the payer to the paying institution, makes payment to an unintended payee, it is submitted that a mistake of fact has occurred. The position of the law in relation to mistake of facts is that, the money paid is recoverable from the beneficiary, who in this case is the unintended payee by means of an action for money had and received or for money paid under a mistake of fact. Also, an affected party can invoke the equitable doctrine of tracing, to recover the money mistakenly 
transferred to the unintended recipient.

The right of the payer or paying bank to recover an amount paid due to a mistake of fact is a common law remedy and is enforced by the plaintiff bringing an action against the payee or the receiving bank for the recovery of money had and received by the defendant for the use of the plaintiff. The claim is a purely personal one and it is therefore enforceable whether the defendant still has the money received by him or not.

Alternatively, a paying bank can invoke the doctrine of tracing. This will enable the former to recover the amount debited from the financial institution. The equitable tracing remedy could be extended so as to enable a bank which is induced to make a payment under a mistake to recover the amount credited from that bank. The court has held that a bank which pays money under a mistake of fact to a collecting bank may either recover the amount paid from the collection bank's customer or from the collecting bank itself to the extent of the credit balance on the customer's account, or may alternatively trace the amount through the customer's account, into any assets paid with it, or receive it, in the event of the customer's insolvency, out of his general assets. (Banque Belge v. Hambrouk (1921); Chase Manhattan Bank NA v. Israel British Bank Ltd. (1981))

It is submitted that if money is paid under a mistake of fact, the equitable title in the property therefore remains vested in the payer and the payee is subject to a corresponding fiduciary duty to make restoration of what has never been his property. The paying bank may, therefore, recover funds paid to the receiving bank under a mistake of fact or, if they are further transferred into an account at another bank, it may recover them out of that account. The bank may also claim and enforce a charge over assets acquired with the funds obtained from it. However, it does not follow that the holder of the account with the paying bank whose account is initially wrongly debited may assert a similar tracing claim. His rights are limited to having his account with the paying bank re-credited.

The grounds of which payment may be recovered because it is made under a mistake of fact do not depend on the manner in which the payment is made: they are dependent on the fact that payment is made under a mistake. Consequently, a payment made due to a material mistake of fact or other such error may be recoverable either from the payee or from the receiving bank, whether the payment is by means of an electronic transfer or any other electronic means.

Furthermore, where a person pays money to another under a mistake of fact, the payer is prima facie entitled to recover the money paid under the mistake of fact (Barclays Bank Ltd. v. WJ Simms, son \&. Cooke (Southern) Ltd. \& Anor.[1979]). The foregoing is possible if the payment made in error was made as a result of a mistake of fact and the payee is not an agent, who had thereafter paid out same to his principal. See the dictum of Sir Greene, MR in Gowers $v$. Lloyds \& NPF Bank (1938).

However, where the receiving institution has paid out the money to the payee the money is recoverable; but in this case, the option is to take out an action against the payee. In such a situation, the receiving institution is an agent of the payee and the latter is the position of a principal and it is the position of the law that it is the principal that can be sued in the above case (National Westminster Bank Ltd. v. Barclays Bank Intl. Ltd. (1974)).

Also, an error or mistake could result from the activities of the staff of the financial institution. For example, authorised personnel in the course of entering information in the database of the financial institutions could enter a wrong digit, which would bring about consequences that are as varied as the ken of the entire humanity. It is submitted that the financial institution is liable to the customer/client in so far as it is proven that the staff acted in a manner, which is less than what is expected of a person of his/ her status position; while acting within the limits of the dictates of his/her employment and in such a situation, the employer - the financial institution - would be vicariously liable.

Thus, notwithstanding the seemingly exotic nature of transactions carried out with the aid of ICT - tools, banks and other financial institutions that have deployed them, are liable to make a refund of the money erroneously paid to them as collecting bank as is the case with in a traditional paper-based transaction.

\section{Systems Failure}

In a situation where a customer suffers financial loss due to an ATM or Electronic Fund Transfer (EFT) systems failure or malfunction, which a financial institution is experiencing or has experienced, the aggrieved customer may decide to seek recompense from the former. The question, which will be a corollary to the foregoing state of affairs, is: "can the financial institution avoid the claim brought against it, or call it pass the burden of settling the claim to another party"?

In resolving the above question, the point of reference will ultimately be the formal contract between the banker or e-payment service provider and the customer. Lord Justice Bankes (Joacliimson v. Swiss Bank Corporation [1921], held that there are a number of implied super-added obligations beyond the one specifically mentioned in Foley v. Hill [1848]. In Agbanelo v. UBN Ltd. [2007], the Supreme Court held that in addition to the obligation as a debtor which the bank 
owes its customer, it is under a duty to exercise reasonable care and skill in carrying out its part of the contract between it and the customer.

However, parties to contracts are in principle, free to limit or exclude the obligations attached to their various undertakings and/or obligations in and arising from the contract by the inclusion in amongst the terms of the contract, an exemption, limitation or exclusion clause (Sagay, 2000, 159 et. seq.). Thus, financial institutions providing e-banking and payment services can and do insert in their terms of agreement with their customers exemption/exclusion clauses.

It is here submitted that where a financial institution, due to systems failure or malfunction, does not meet up with its obligation under the contract between it and its customer; the former is in breach of the terms of the contract, and it amounts to a fundamental breach when the aftermath of the failure of one of the party to perform a primary obligation has the effect of depriving the other party of substantially the whole benefit which it was the intention of the parties that the injured party should obtain from the contract.

The focus of this discourse presently turns on whether in circumstances as that espoused above, the inserted clause will at all times avail financial institutions in view of the duty upon them. The issue is resolvable with the application of the time honoured canons of the law of contract as well as the provisions of the laws of the various States of the Federation which regulate contracts and contractual agreements to the relationship between a financial institution which has deployed e-tools in the delivery of services to its customers and the latter. The leaning of the law in Nigeria has made it impossible for a party that is guilty of a fundamental breach to rely upon an exemption clause so as to escape liability (IMNL v. Pegofor Industries Ltd. [2005], 17 - 18 and 24 - 26: section 190 of Contracts Law, Cap. 32. Revised Laws of Anambra State, 1991).

As a result of the foregoing, it is submitted that a financial institution which has deployed e-tools and which has incorporated an exclusion/exemption or limiting clause cannot escape liability where there has been a system failure as a result of its negligence which has resulted in a fundamental breach of the contract. This is because, a fundamental breach of the terms of the contract amounts to a destruction of the substratum of the contract and would entitle the aggrieved party to seek to refuse further performance of the contract where same is possible; and any exemption/exclusion clause inserted in the contract will not be enforced in favour of the e-tool deploying financial institution. The position of the financial institution is worsened if it is shown that it had been negligent.

Furthermore, in the case where there is no formal contract or express term between the parties - like is the case of the relationship between some banks in Nigeria which provide e-services who compel their customers to use ATM cards without the latter applying for signing any document relating to the ATM facility, or agreeing to any express term in relation to the ATM facility - insofar as there is a relationship between the financial institution and the customer that could be construed as that between a professional and a client, it is implied that the financial institution will exercise reasonable care and skill in rendering service to the client.

\section{Conclusion}

There is no gainsaying the fact that the incorporation of ICT tools into the mechanics of service delivery by financial institutions in Nigeria poses challenges to the legal regime in the polity. However, without doubt, it is submitted that the challenges are capable of being taken care of by the provisions of the polity's legal regime. To this end, judicial activism is enjoined: for it is with this that the dynamics which these new challenges pose can be met, head on. It is submitted that this imbroglio is resolvable by the grafting on to this esoteric situation the principles of tort and the provisions of the law of contract.

The adoption of the foregoing proposal is a better strategy compared to the clamour for the making of a body of laws targeted at the e-milieu as well as ICT, for it will allow for piecemeal development of the law in relation to transactions within that environment. It is also submitted that an attempt to bring the law in pace with technological change by enactment amounts to an exercise in futility for as fast as the law strains to catch up with technological change, the latter moves ahead to outpace the law.

\section{References}

\section{Book}

Sagay, I.E. (2011). Nigerian Law of Contract (2nd ed.) Ibadan: Spectrum. P 159 


\section{Cases}

Agbanelo v. UBN [2001] 7 NWLR (PI.666) p. 534 at 550 and 561

Barclays Bank v. WJ Simms, Sons \& Cooke (Southern) Ltd. \&. Anor. (1979) 3 All ER 522

Banque Belge v. Hambrouk (1921) 1 KB 321

Benson v. Otubor (197 5) 3 SC 9

Chase Manhattan Bank NA v. Israel British Bank Ltd (1981) Ch. 105

Foley v. Hill [1848] 2 HLC 28

Gowers v. Lloyds \& NPF Bank (1938)1 All ER 773

Joachimson v. Swiss Bank Corporation (1921) 3 KB 110

Latunji v. Co-operative Bank of Western Nigeria Ltd. (1979) 12 CA 335

Nig. Advertising Service Ltd. v. U.B.A. Ltd. (1965) NCLR 6

IMNL v. Pego for Industries Ltd. [2005] 15 NWLR (Pt. 947) p. 1 at 17, 18,24, and 26

Journals

Aniyie, I. A., (2010) E-banking and Payment Systems: An Appraisal of its Forms and Corollaries (unpublished) 35 Uvie, A., (2003) Valucard Nigeria Plc., Merchant Briefing Manual.

Inaugural Lecture

I. Igbinovia, P., (2008) "The Criminal in All of Us: Whose Ox Have We Not Taken?", University of Benin Inaugural Lecture Series No. 71

\section{Statutes}

Contracts Law, Cap. 32, Revised Laws of Anambra State, 1991

Consumer Credit Act 1974

The Central Bank of Nigeria Guideline on Electronic Banking in Nigeria, August 2003

Bills of Exchange Act, Cap. B 8 Laws of the Federation of Nigeria, 2004

\section{Web Material}

http://en.wikipedia.org/wiki/Personal_identification_number. (accessed 18/04/08) 